have seen that modern prostatectomy has taught a better way of disposing of the troublesome class of cases that furnished most of the difficulties met by the early lithotritists. Having emphasized this additional exception in which a cutting operation should be preferred to Jitholapaxy, 1 shall close by repeating the assertion unade in tiat earlier paper:

In my opinion, we have in litholapaxy the operation of moice for the removal of most stones. While this is the rille, there are exceptions to it, and the varying conditions surrounding stone in the bladder will now and then lead us to choose some other operation for their sufest removal.

The surgeon who best appreciates these varying conditions, and selects in each case the operation which most surely avoids the dungers surrounding "that particular patient," will arive at better results than any advocate of a special operatiss, however expert.

1 Murlboro Street.

\section{SUPRAPUBIC CYSTOTOMY FOR VESICAL CALCULUS}

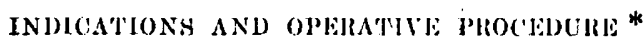
WIJLIAM E. JOWER, M.D. CLIVVEI.AND

There are but two operative methorls now considered practical for the treatment of stone in the urinary bladder. One is the crushing of the stone and the jemoval of the fragments through the urethra; the other is the opening of the bladder suprapubically and the removal of the stone through the incision.

He would be obdurate indeed who did not acknowledge the wonderful invention of the lithotrite and the achievements accomplished by its inventor. At a time when any cutting operation calried with it such a high mortality and the convalescence was so prolonged in those who survived, the lithotrite, with the skilful touch of Bigelow, was truly a blessing; but the conditions that prevailed then with regard to the cutting operation no longer exist to-day. Little advancement, if any, las been make for the crushing operation, while each year brings a better record for the suprapubic operation.

'To say that either. operation should be used to the exclusion of the other for all cases of stone in the bladder would be ill-advised; but the cases generally recontmended for the use of the lithotrite by the advocates of litholapaxy are, as a rule, selected cuses and naturally would have a lower mortality-rate, no matter what kind of operation. Surgery is rapidly turning from the dark to the light, and blind operations or those depending cutirely on the sensation of indirect touch must be replaced, wherever possib]e, by operntions conducted by inspection of the field or by the direct aid of the fingers. We all know that it is possible by large experience to become fairly accurate by indirect palpation, but it can never be so nearly exact a method as that which depends on secing or direct feeling.

'Whe opportunities for any one person in this country to acquire a large experience with the lithotrite within any reasonalule time are very limiter ; material in clinies j: not suffieient to give the student the practical expericence necessary to do a successful Jitholapaxy, and celtainly no one would recommend its use by the untrained;

* Joad In tha Symposium on Trentmont of Veslonl Calculus in

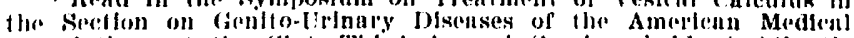

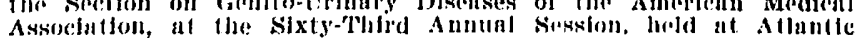
Associntion, al 1].

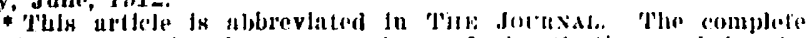

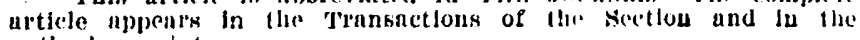
liutlion's inprints while the opportunities for teaching suprapubic opening of the bladder are quite common, there being many cther conditions besides stone for teaching this technic. in India where so large a proportion of natives have vesical calculi, an extensive experience may be acquired in a comparatively short time; as most statistics for the lithotrite come from India, the comparison is hardy fair.

Most advocates of litholapaxy admit that the stone should be freely movable, that there should be sufficient bladler capacity, and that the wrethra should be of sufficient size; also that a very large prostate, an encysted stone or a stone with a foreign boily as a nucleus are all contra-indications to the sucessful use of the lithotrite. For these more or less difficult cuses suprapubic eystotomy is recommended. If, then, the mortality-rate should be somewhat higher for the cutting operation would the comparison be fair?

Among the causes mentioned as being responsible for deaths in suprapubic operations is peritonitis. This should no longer occur, for with better aseptic methods and better teclinic the dangers of peritonitis are reduced to a minimum. Better local and general anestheties have reduced the danger of shork from the operation; and hetter methods of dealing with the wound have shortened the period of convalesenee and reduced the complications to a minimun?

The complications and mishaps of the lithotrite, when they do occur, are neally always serious. I am treating now a most persistent stricture resulting from the use of the lithotrite by a collengue. In this case there had been an extensive laceration of the metlura.

\section{INDICATIONS FOH SUPRAPUBIC CYS'TO'TOMY}

Overenthusiastic exponents of litholapaxy may make the statement that they have never seen a stone too large or too hard to be grasped by the lithotrite, but their experience is scarcely borne out by the experience of other surgeons or by the many reported cases in medical literature. Fven in the special stone number of the Indian Medical Gazette expert operators confess that this condition does exist. 'The cuse reported hy Richards ${ }^{12}$ is a good illustration. 'J he stone weighed $\approx$ pounds; lithotrity failed; perineal incision failed because the stone had to be chiseled; and the stone was finally removed suprapubically, the wound healing l'eadily. In my own practice there lave been eight cares with large hard stones which I feel could not have been removed without great difliculty by any other than the suprapubic route. 'The patients made quick recoveries without complications.

'lie operative treatment of encysted or adherent calculi is always the high incision, as the many published cases prove. Inspection is absolutcly necessary here. I lave had three such cases; in one a stone abont $2 \mathrm{~cm}$. in diameter was enucleated from a pocket in the region of the trigonum, only the very tip showing. In another the stone was firmly adherent behind the prostate. In the thind case cystoscopy showed a calculus cmlsedded in the mucous membrane over the right hall' of the trigonum. 'This case is of further intorest in that the patient returned in six montlss compluining of the old trouble; cystoscopy showed the diverticulum at the site of the former stone. Again suprapubic incision was made, several soft stony deposits removed and the diverticulum dilated, since which time the patient has been in good health.

Where multiple stones are present the superiority of the suprapubic method is hardly to be doubted, for

12. Itlchurdy : Lancet, Loudon, 1908, 11, 2:30 
exposure of the operative ficld is necessary for a thorongh scarch. In my practice l have had ten cases of multiple caleuli, in one of which I removed ninety-three stones, six the size of filberts and eighty-scven ranging down to the size of a grain of whent; there was extensive trabeculation. 'This patient was 84 and made an uninterrupted recovery.

The suprapubie operation is gencrnlly accepted as the operation of choice in the young. The operations of Milton and Assendelft' nre good proof of the wistom of this. Even 'S'hompson did not advise litholapaxy in children. My youngest patient was a 19-month-old baby. 'There was a quick convalescence.

'T'he presence of alculi in old men is another indication for the suprapubic incision. Thomas, ${ }^{13}$ in an article on ralculus in old men, gives the histories of four cases in which the calculi were so situated belind the prostate that the lithotrite could not grisp them. The stones were lemoved suplapubically and the patients made cood recoveries. My seven patients, all over \%o, left nothing to be desired so fiar as operative recovery was coneerned.

lixeept in the hands of the most experienced, prostatic lypertroplyy oflers obstruction to the lithotrite, there being few surgeons who will not prefer the suprnpulpic method. Six of my patients had marked prostatic hypertropley, on three of whom 1 performed a prostatectomy at the same time.

The location of the calculus projecting from the vesial end ol the ureter is another jndication for the suprajubic method. I lave had several very interesting cases of this kind; also two eases in which the stone was wedged in the neek of the bladder' and considernble force was necessary to dislodge it. It could hardly have been removed in any othes way.

The presence of a loreign boly as a nucleus is nnother hindrance to crushing. Many such anses are on record. My anses of this kind are three in number, the nucleus being a hair-pin in one (ase, the wick ol a taper albout o inches long in mother, and a piece of wax in the thiret. Culculi associnted with tumor also hinder erushing and " strictured urethra almost necessitutes the cutting operation.

$\Lambda$ recent case in my practice was of more than general interest. "Jice patient, a man aged $6 \%$, suftering from severe ascites and marked myocmaditis, was in almost continuous pain, due to n bladdes contracted firmly about a very rough stone. 'There was practically no bladder enpacity. Five liters of clombly sermm were Irawn from the nbilominal avity the ray before the everation. Under nitrous oxid and local anesthesin, a Jarge culculus was sucessiuly removed suprapubically.

'The reports of Iakeside Hospital, Clevelnnd, for the ten years from 1900 to 1910 show forty-six operations for vesical calculi; thinty-eight were done suprapubieally, seven were litholapaxies and one was removal of the stone by dilatation of the urethrn. Four denths ocenred in the suprapubic cases, all four being complicated cases. Cine mun of 68 had acute double hydronephrosis; another of 74 , with a very wenk heart, had a prostatectomy at the same time; the third lad marked prostatic hypertrophy and the bladder was divided into two ('ompartments by a small tound the fourth patient, a man of 55, showed $n$ relntinous condition of the bladder unucosa, the bleefling being a constant oozing. 'The mortality of the suprapubic operations was 10.5 per cent. One denth occurred in the litholapaxies, that of a boy of 12 who died from severe lacuration of the

13. Thoinas: Lancel Lowdon, 1900, 1, 1652. bladder. 'The mortality of the litholapaxies was 1-1.2S per cent.

One of the objections to suprapubic cystotomy is the prolonged convalescence. This was a valid objection when the bladder was drained, but it is no longer necessery to drain the bladder after removal of stone or tumors. If the bladder is properly elosed, a week or ten days is all the time necessary for a eomplete cure. I have been elosing the bladder in practically all suprapubic operations, with the exception of suprapubic jrostatectomy, and have more than 90 per cent. of priniary unions.

For the suceess of this operation certain points in the techunic, which 1 have described in a previous paper, are necessary. In brief they are as follows: The cut eflges of the blachler should not be grasped with crushing forceps. 'The edges must be carefully approximated while the wound is on the streteh so that the stitehes will not be separated when the bladder is distended with vine. 'The ligature must be absorbable. My personal experience consists of fifty-three suprapubic operations for stone in forty-nine cases, with no denths. There were four cases of recurrence. Good recoveries resulted in all cases. 'I'wo of the forty-nine patients were women. 'Three patients were below 15 years of age; sixtecn le.tween 15 and 50 ; twenty-nine between 50 and 84 . Whe youmgest patient was 19 months; the oldest, $8+$ yenrs. The average age was 53.4 years. In thirty-three cases the bladder was immediately closed, leakage occurring in only three cases and in two of these only a small mount, and for a short time.

Until a practical observing lithotrite is invented, which will give the operator the opportunity of seeing the ficld of operation, suprapubic cystotomy for stone must remain the method of choice by the majority of operators.

10.21 Prospect Avenue.

\section{ABSTRACT OF DISCUSSION}

ON I'AlELS OF DIRS. CABO'L AND LOWER

1). Jolis Mreis Swas, Canton, Chim: In the Canton llos. pital of Sonth China, during the last twenty yenrs 1 have had 1.0.s lithotomy operntions for urinary calculi, 950 of which were by the old lateral perineal section and about fifty by the supmupube. In addition to that and during my earlier experionce in the trentment of this disease, 1 had to denl with nbout as by litholapaxy. 'There are two or three factors that lave cansed us to aclopt the operation we have generally done: lirst, the age of the patient. Ont of $1,058,330$ were under 10 years of age, mal we all know that it is not nearly so ensy to use a lithotrite in putients under lo yenrs of nge as it. in the adult. The fuetor that first influenced me with regare to the operation best to do was the mortality-rate. My predecessor, J). John G. Curry, was one of the most fumons lithotritists in his time, and we lave in the hospital one of the bout outfits for lithotrity. In the first few years of my experuene the mortality-rate ranged higher in the operations for litholapaxy thun in the ordinary lithotomy, The second and perhaps the most important factor was that there was recurrence after litholapaxy. Dr. John G. Curry was a rkilled lithotritist, and yet $I$ have foumd that anywhere from six montlis to a year and a half after litholupuxy our patients returned with recurrent stone. Recurrence very rarely ocenrs after lithotomy. Third, when we have from ten to twenty operntions in one day, the question of time must be considered. from two to flve minutes from the time the pationt is anesthetimed until he is ready to be removed from the table will fencrally ullow of a lithotomy. Lithotrity cannot be done in that time. The advantage to the patient, the liability to the quickness, ense, convenience roturn after litholapaxy, and the quickness, ense, conve adopt 
lithotomy, either suprapubic for the larger stones, or the ordinary lateral perincal for the smaller ones. lixclusive of serious orgunic disease, aside from kidney or bladder, our mortality-rute after lithotomy, either suprapubic or perineal, has been reduced to 3 per cent., and in one single year I did sixty-two perineal and suprapubic sections with no mortality.

I). A. J. Cuure, Boston: I do not know whether you are all aware that J1. Cabot was the pupil and great friend of 1)r. J3igelow, our surgical prinate of Boston, who, we think, did so much in establishing this operation. In spite of the statistice from Canton, I do not see how anybody can hold to the cutting operations. It seems to me that the operation of litholapaxy is so much easier. In uncomplicated cases it does not seem to me that we ought to consider the suprapubic operation from the point of view of the patient. I disugree with Dr. Swan as regards the time. That is not an argument. It is the surgeon's time as compared with the patient's convaleseence.

b). Huar II. Youna, Baltimore: I hesitate to say anything when there is a man present who has done 1,058 stone operations, an appalling experience to the rest of us. I agree with ])r. (abot and Wr. Chute in the thought that it does seem a shame in this dny of the cystoscope to do a cutting operation for stone in the blader in uncompliented cases, when it is so easy to erush this foreign body. Of course there are reports of a few cases of rectal fistula and a certain number of cases of incontinence in which the lateral perineal operation las been employed, so that the Fnglish surgeons in India have practically given up eitloer the median or the lateral lithotomy. We have all seen severe suprapulic infections, and occasionally extravasation. (he of my putients died from interrectus infection following the removal of a calculas. The fact that these complientions are not possible after the litholapaxy operation ought to lead us to try wherever possible a erushing operation. J.itholnpaxy has fallen into disfavor on aceont of the length of time consumed, and on nceount of the difficulty in finding the last fragment which often remains and leads to the recurrence of stone.

Chismore was pight in trying to perfect the operation by changing the instrument so thint the stones could be sucked into the blates, caught there and crushed withont hunting all over the bladder for them. 'Those of you, however, who have tried Chismore's instrument know of the difliculties. It was medhanically not a well-eonstrueted instrunent. One could not handle it so quickly and ensily as the Bigelow. 'Tho cvacuating tube was so amall that it was impossible to get anything except the small fragments through it, although $I$ think that the evacuating prineiple was a good one. Therefore, I constructed a lithotrite, fushioned after Bigelow's prin(iple, with the handle hollow, a stopreock and an evacuntor attached to the instrument, thus muking it possible to larve an assistant work the evacuator while the surgeon is arush. ing. Then, if desired, it is easy to introduce a straight cystoseope through the instrument, hunt for any fragment, piek it ii) and erush it. There are certain difficulties in the perfection of this instrument which have made me hesitate to pat it on the market. 'lle difliculty is in the laduncing of the metals; 1o lave the blade large enough and strong enough, whether the old Jigelow blade or a ferestruted posterior blade is nsed. Freyer and Keegan have shown that pushing of fragments llowough the fenestra does no harm. A fenestrated posterior blade makes a more effective crushing instrument than' Jigetlow's hlade. So my instrument, which is made after the plin. ciple by Jeitor, has the fenestrated blade. It seems to mo that the great trouble with the litlotrite is the introluction of one instrument after another and the hemorrage that results from the passing of the instruments through the posterior irethr. With an instrument introluced only once there is practically no bleeding, so that cystoscopy is really quite prictimble.

Dr. Lotrs F. S(mumer, Chicago: I should like to drow attention to the phrise. "onlarged prostate complicated with atone," Wluch seems to be a general term. I am guite sure, however, that if we nso the rystoscope, we can often readily ser that we are denting with in primary ntone, and that the prostute has alssolutely nothing to do with the condition. In the past three yenrs 1 have arushed stones in three patients over (3i) years of age. All had been advised to have a prostatectomy and naturally removal of the stone, In all three instances litholapaxy has given perfect results. I think that it is well worth taking into consideration that it is the stone that is causing the trouble and not the prostate, and that we must not always think that the prostate lans to be removed with the stone.

Dr. Euckese liumen, New York: T have always felt that there was a very lurge and useful field for litholapaxy. 'l'here is no doubt that it is an operation which repuires great dependence on the sense of touch, and if a surgeon has that accomplishment, he will find in muly cases that it will be the simplest thing in the world to crush a stone and to remove it; by so doing he' will subject his putient to less danger and pain than by eatting. There are eases in which stone is only secondary to some other condition, nnel of course, one does not want to try to crush. I think that is the case in a great muiny conditions of the prostate; not all of them, as Di'. Schmidt lans just pointed out. For instance, if a pliosphatic stone is secondary to foul urine in the postprostatic culdesac, there is little use in trying to erush that stone and leave the foul urine. It is better to remove botl the prostate and the stone. If there is a hard stone and a clean bladder in a condition of prostatic retention, then it may be worth while to crush the stone. One eurious point that is brought up sometimes is the tolerance to stone. One sees a certrin class of cases in old men who have an extreme amount of tolerance; in such cases, for instance, there exists a mulberry calculus of the roughest kind with perfectly clear urine and no pain. l'he only way I cun explain that condition is that these men lave so much prostatic obstruction that the stone during urination lies in the culdesac and consequently is not bronght into the grip of the: neck of the bladder nt the end of the act. I have never seen a young man who larbored n stone like that without a great deal of pain in the bladder.

Dr. Grontis S. WuJTesmm, Portluml, Ore.: I linve just neen the large collection of stones from the Canton Hospital her'e on exhibit. 'l'hey are a most wonderful eollection and some of them could not have been erushed. Some are as big as paving stones. Conditions nre a little bit dillerent in this comntry from those in Canton, and it seems to me that we see the smaller stones. Wducated people, when they have any thing the matter with them, go to see a physician instend of waiting until the stones are large. Here, litholapaxy is betier than any cutting operntion. It keeps the patient in the hospital but twenty-four hours, and the number of cases of recurrence that one sees after litholapaxy, with a proper cystoseopy afterwards, in almost nit. In neglected cuses with large stones a cutting operation is of ten preferable.

Dr. Wildiam 'T. Bowderd, Chicago: In nearly a hundred of my operations for stone, ealeuli were removed neilher by crusluing nor supmpubically, but by a simple median urethotomy. I have no clould that had I been bronght up in the classic whates of lanvard I should have removed some of these by a crushing operation. J3ut median urethrotomy gives advantiges which litholapaxy cannot furnish; that is, drainage of the bladder, with less dauger than a suprapubic operution. So J think we should not ullow to go unchallenged 1)r. Lower's stutement that there are but two pratical operations for stone in the bladiler.

1) A. A. 'T. Cajo', Bonton: Our experienee in litholupnxy in chililen in this comntry, of course, is nothing as compured with the experience that they have in Chima and Indin, but against the remarks just made by Dr. Swan we must remember the renurks of keegun and Freyer. 'They opernted among " similar clientele, had an enormous number of stones and foumd the rrusling operation in children quite feasible. I have had very fow. Someone snid that it was a very diflicult operation in children. 'That is all wrong. It is very easy. The bladder in children is small and globular and the stone cannot get away. One must be gentle, but the munipulation is ensy. In the operations 1 have performed $]$ lane loen delighted with the ense with which they were done. Recurrence has always be:n 
an opprobrimm of the erushing operation. There is thuger in any operntion of frugments bejug left. I have removed stones in a number of instances after suprapubic operations doue for the removal of the prostate. When one leaves a suprapubic wound it lenves a granuluting surfuce on the inside, on which colcareous matter collects and acts ns a mucleus for stone. After litholapoxy 1, always wash my putient out nbout ten lays later, with the iden that somewinere some little fingment nay lave eaurht among the folds and not have lees removed. I remember one anse in which I did a number of operntions. 'The stone disl reeur. 'The putient had three or four lumbled stones at the first operation, all the why from the size of $u$ grood-sizesl beun down to a gruin of whent. It was one of my early anses, mal I did not wash the juticut out afterward, and within less than a year ho was back again for a second operution. I removed the stones again; they were multiple. A fortnight later I wasled ont 150 mimute separate stones from his bladaler. A weok later 1 washed ont fifty. I washed him out onee? a week nutil I washed him onee or twiec without getting auy. I think that subsequent washing out is an important part of the operation.

Dr. Young spoke of 1)r. Bigrelow's lithotrito. I think that he is maware of the fact that Dr, Bigelow devised a fonestruted lithotrite which he occusionally used. The fenestrated lithotrite cuts the large stones very ensily. In operating on children 1 always uac a fenestrated lithotrite. After he land broken the stones up bigelow prefered the solid blude benuse loo could put it down in the bottom of the bladeler and exush the stone ensily without any danere of thrusting fragments fhrough ngainst the floor of the bladder. In ny enrly anses I constantly opernted in ennes in which the prostates were not vemoved. I have often acen the irritation dismppens and tho resialual urine full from severnl ounces to u few drang ufter removal of the stone. One field for stone removal is whem they first come into the blahler. With my litholajaxy pump ] luve in my olliee removed puite a mumber of remal stones that had been passed from the kidney juto the bladdor and then Jual not passed out. Of course, behind an enlarged prostate timt has any residul urine whatever, a small stone has a very small clumee of being pussed ont, and in these cases the use of the pump will save the patient the subsepuent formation of a veraical stone.

DR. IV. J'. Jowkr, Cleveland: 1)r. Swan has given statistices for eystotomy far better thin muything I lave to ofler. The lithotritists are asking us to do the hard operations and they will do the ensy ones. Whe only thing we usk is thut we be permitted to do the casy omes us well. If the suprapubic rystofomy is properly done and the bladder elosed, the patient has no greater diseomfort than after the nse of the lithotrite. lt is clombtful if he lias as much lecense of less tramma to the urethra, for there is niways a certuin amount of trimma to the urothra after the uso of the lithotrite and urination is more or less painful.

\section{STMINAT VESICULO'TOMY}

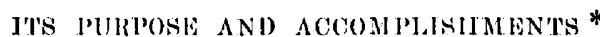

\section{GUGLNE FU\}LIR, M.D.}

\section{NEW Yolk}

Sine the operution of seminal vesieulotomy has been before the profession for a considerable period of time, no attempt will here be made to describe the procedure itself. All those desirous of such information are referred to my previous articles. ${ }^{1}$ My first article was written during the experimental stage of the work; the seeond, after the procedure had established itself on a firm, practical basis. In the second article it will be seen that some of the original experimental technic was

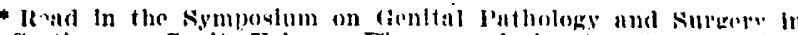
the Section on Genilo-Itrinary IJsellses of the Amellean Medieal

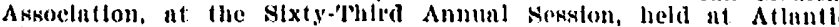
City, Junc, 1912

1. Fuller: 'Tun Jonkna a. A. A., Mny 4, 1001, p. 1228; Med. Rec., New Yol'k, Oct. 30,1909 . abandoned and that improved features were substituted. At present, having more than doubled my surgical experience with the operation since the 1909 article was written, my cuses then having numbered only 126 , I naturally feel that my techic and surgery are more competent than they were three yenrs ago. Still, in the way of a general description of the operative procedure itscli, there is little to add.

'T'o any one wishing to perlect himself in this particular, the following suggestions are offered: The anatomy should be studied and dissections should be made on the cadaver. In accomplishing such dissections the cadaver should be placed in the knee-breast posture. thus simmlating conditions pertaining during actual operntion. Dissection should be made without cutting into the muscular structure of the perinenl body, the rectal sphineter muscle or the blood-ressels encircling the anus. If this is so done, the bursal space between the rectum and the prostate is entered without injury to a bloodvessel of any size. In fact, in the performance of the actual operation the tying of a single blood-vessel is only exceptionally necessary. After the bursal space is once entered, the finger-tip suffices, except occasionally when dense pathologic adhesions exist, in accomplishing a separation of the rectal wall from the prostate and seminal vesicles.

Asite from an acpuaintance with the anatomy of the region traversed by the operation, familiarity with the regional anntomy of the part to be attacked is most esscritial. In common professional parlance, the term "prostate" is seemingly made to include not only the prostatic body proper, but also the seminal vesicles; and should an inflammatory or neoplastic tumefaction occupy a part or the wholc of the postprostatic space, such lesion is generally classed also as prostatic, the iden that anything else could exist calling for a differentiation of the diagnosis not being apparently even thought of. As the result of a regional dissection, just what constitutes the prostate, the seminal vesicles and the outlying region of the postprostatic space will become apparent.

When one considers that the seminal vesicles are envities for holding fluid, the walls of which, ns with the bladder, are made up of muscular structure lined interiorly with mucous membrano, it is not difficult to pieture the pathologic conditions so frequently encountered. Such conditions in the grent majority of instunces lave to deal with intraseminal vesicular infections of valious descriptions, most of which have entered the avities by the ejaculatory ducts, though in a minority of instances the invasion has been effected by penetritions through the sae walls. The distention of the sate cavities due to muscular atony may represent a lesion in connection with which there is no intraseminal vesicular infection. Severe grades of infection are not simply intravesicular, but involve the muscular walls of the saes or (and this is frequent) invade also the outside fibrous lympl-spaces, a periseminal vesiculitis of greater or less degree resulting.

As the seminal vesicle discharges its contents by the long narrow ejaculatory duct und only at infrequent intervals, it is readily seen that the organ is not well equipped by Nature to throw ofl spontancously an infection, even when confined to the intravesical cavity, and much less so when the process has extended so as also to involve the sac walls and the perivesicular tissues. In very extensive infections in which pus collects in the postprostate space outside the seminal vesicles, Nature, postprostate space outside the seminal vesicles, Natader through the trigonum, into the rectum by perforating 